\title{
Study on Chinese-English Translation in Tourism Culture of Internationalization-A Study of Chinese Poem of Tang Dynasty "Song of the Parting Son"
}

\author{
Zhao Lin \\ Liaoning Economic Vocational \& Technical College, Shenyang, Liaoning Province, China
}

Keywords: Beauty in Form, Beauty in Translation, Beauty in Rhyme, Beauty in Vocabulary

\begin{abstract}
In recent years, with the rapid development of China's economy and the vigorous development of the tourism industry, more and more foreign tourists to come to China,and English translation in tourism has heightened the importance of its cultural transmission.Chinese Poetry of Tang Dynasty(618-907) has a long history and good reputation all over the world."Song of the Parting Son"written by a poet called Meng Jiao (751-814)has been very popular until now.From different views, many translators both home and abroad have contributed a lot of English versions on this poem. Every version of them has its unique attraction with the thoughts, values and feelings of the translators. From the four aspects that are Beauty in Form, Beauty in Translation, Beauty in Rhyme, Beauty in Vocabulary, the compensations among the selected English versions of the poem is to be conducted and studied in the paper. The beauty of the versions, the commitment of the translators and the charm of English version of the poem can be appreciated through the study.
\end{abstract}

\section{国际化背景下旅游文化中汉译英研究一一唐诗《游子吟》英译比较为例}

\author{
赵凛 \\ 辽宁经济职业技术学院, 沈阳,辽宁,中国 \\ 910624075@qq.com
}

关键词: 形美；译美；音美；词美

中文摘要. 近年来, 随着中国经济的迅猛发展和旅游产业的蓬勃发展,越来越多的外国游客到 中国来旅游观光,旅游英语翻译的作用也日益凸现出其文化传播的重要性,中国唐诗历史悠久, 世界闻名, 孟郊的《游子吟》更是脍采人口的佳作, 国内外很多翻译家对这首唐诗进行了翻译, 角度迥异,各有千秋, 从中看出译者的良苦用心。文章从形美、译美、音美、词美的角度对遴选 的几个译作进行比较分析, 窥视译作之美、挖掘译者的用心良苦和让世界旅游者感受英译唐 诗的鬼米力。

\section{1. 引言}

诗歌翻译是一门艺术, 是一种再创作。中国唐诗宋词属中国文化的精华部分, 外国读者对 中国古诗产生了浓厚的兴趣。随着中外文化交流的开展, 整个20世纪中国的诗歌越来越为国 外读者所喜爱。很多专家持着 “诗歌是不可译的” 的观点。但是, 事实上诗歌翻译的大量出现 都表明了诗歌的可译性。译诗只是一种类似与原诗的形式, 是一件跟原诗的艺术效果相近的艺 术品。译诗难, 评论译诗更难。汉诗英译浩瀚如海, 本文仅尝试从鉴赏的角度以唐诗《游子吟》 
为例对几个译作从形美、译美、音美、词美的角度进行比较分析, 期待能够展示英译唐诗的 魅力。

\section{2. 汉诗诠释}

游子吟
慈母手中线, 游子身上衣
临行密密缝, 意恐迟迟归。
谁言寸草心, 报得三春晖。

这是一首母爱的颂歌。其作者孟郊仕历简单，清寒终身，为人耿介倔强。故诗也多写世 态炎凉。他做诗态度严谨, 入深履险, 甚至含着涩味。《游子吟》却是自然亲切, 表现出骨 肉深情。此诗体例一首五言古诗。其实五言古诗是汉、魏时期形成的一种新诗体。它没有一 定的格律, 不限长短, 不讲平入, 用韵也相当自由, 但每句五个字的句式却是固定不变的。 诗中亲切真淳地吟颂了伟大的人性母爱。诗的开头两句, 所写的人是母与子, 所描绘的物是 “线”与 “衣” ，然而却点出了母子相依为命的骨肉之情。中间两句集中写慈母的动作和仪 态, 表现了母亲对儿子的深笃之情。虽无言语, 也无泪水, 却充溢着爱的纯情, 扣人心弦, 催人泪下。最后两句是前四句的升华，以通俗形象的比喻，寄托赤子炽烈的情怀。 译文版本如下:

译文 (1) 徐忠杰:

\section{A Roamers Song}

My benevolent mother

With thread and needle in hand,

Mends the garment I have on,

Ere I leave my native land.

More stitches ,ere I take leave,

To hold the seams firm and fast.

As itinerant worker,

To come home Id be the last.

With want can I repay Ma?

Whatever others may say,

For what she has done for me,

Her ,I can never repay.

\section{译文（2）龚景浩：}

\section{For Her Son Wholl Be Away for A While}

Needle and thread in doting mothers hand

Turn out garments for her son out to roam the land

She puts in more stitches een as he leaves

And frets that his homecoming may be moved back.

Who says the tiny inch-tall blade of grass

Can eer repay the warm sunshine of spring?

\section{译文（3）许渊冲:}

\section{Song of the Parting Son}

From the threads a mothers hand weaves

A gown for parting son is made,

Sewn stitch by stitch before he leaves

For fear his return be delayed.

Such kindness as young grass receives,

From the warm sun can be repaid?
译文（4）曹顺发:

\section{Song of the Parting Son}

The thread in hand a mother weaves, And her boys garments is thus made. She sews and sews before he leaves, For fear he d be homeward delayed. Could the kindness a grass receives From the spring sun be clean repaid?

译文（5）Robert Kotewell \& Norman Smith:

\section{Wanderer's Song}

The thread from a fond mother's hand

Is now in the jacket of her absent son. 
As his departure came near, closer and closer was the stitching. Her mind fearing that his return would be delayed and delayed. Who says that the heart of an inch-long plant

Can requite the radiance of full Spring?

译文（6）施颖洲:

In loving mother's hands the thread

On rover's body the array.

Before he leaves, she sews and sews;

For she dreads, he may stray and stray.

Who says the heart of an-inch grass

For full spring's sunlight can repay!

译文（7）曾冲明:

\section{Mother's Love}

The needle with a thread in mother's hand is flying

Over the cotton coat of her son before his parting.

Closer and closer with attention and love she stitches,

Fearing that his return would be delayed and delayed.

The mother's love is as warm as the sunlight indeed

While the son's repay would be as small as a grass.

\section{3. “形美” 对比}

《游子吟》包含六句,环环相扣,形成一个不可分割的整体,若抽出其中一句或两句并无诗 意可言。诗的首句似平地奇峰，每句都令人产生一个疑问,下一句解答了这个疑问,而又令人产 生一个新的疑问, 到最后一句才揭开谜底。可以说六行诗一气呵成。也可以说这首诗采用的 是层层倒叙的手法, 到后来才道出原委。从形式看,英语诗歌通常一句分成数行, 行与句是不 一致的，所以 《游子吟》的形式特点很适合用英语来表达。译文（4）在前者译文（3）的基 础上进行加工, 尤为整齐和美观, 符合原诗的整体的效果。也是环环相扣, 一问一答, 翻译 出译文味道。译文(1) 在整体布局上, 属于增译, 原诗六句话, 而译文十二句, 意思完整。 而译文（6）明显不工整，长短不一，与原诗的“形美”差距甚远。

\section{4. “译美” 对比}

直译是既保持原文内容、又保持原文形式的翻译方法或翻译文字。意译，也称为自由翻 译, 它是只保持原文内容、不保持原文形式的翻译方法或翻译文字。直译与意译相互关联、 互为补充, 同时, 它们又互相协调、互相渗透, 不可分割。译文(1) 对原诗结尾句采用意译,

"With want can I repay Ma? Whatever others may say, For what she has done for me, Her ,I can never repay。”道出了作者的本意, 更显母爱之伟大和儿子感恩之迫切。译文(2)出于原诗尊重 在后两句子上采用了直译: “Who says the tiny inch-tall blade of grass, Can eer repay the warm sunshine of spring?” 译者为了迎合原诗所直接事物而采用直译，看上去过于忠实原文 但是过 于直白, 过于牵强运用, 尤其将 “the tiny inch-tall blade of grass” 翻译为草的娇小叶片来表达 “寸草心”，显得刻板和突兀。相比较, 译文 (3) 对结尾句处理得较好: “Such kindness as young grass receives，From the warm sun can be repaid?” 意思是 “小草所接受的来自暖阳的关 爱它怎么能报答得起呢? ” 译文 (7) The mother's love is as warm as the sunlight indeed While the son's repay would be as small as a grass. 意思是： “母亲的爱如阳光般的温暖，儿子的回报 却如小草般泪小”，结构和布局都与原诗相吻合。堪称佳作，意义深刻入理，耐人寻味，意 境逼真，情节感人。 


\section{5. “音美” 对比}

许波冲先生主张用格律英诗译中国格律诗。吕叔湘先生, “英文诗和中文诗一样也是押韵 的”。英文诗也有和中文诗的平入相当的节奏, 就是轻音和重音的配置。以上多种译文韵脚押 得好,但是这并不等于说未用韵的自由体诗就译得不好,从声音效果看译文（6）也不错。译文 (1) 很注重押韵, 如, firm and fast的头韵; 而且译诗的整体带有abab格式, 颇有英诗的味道, 让英语读者倍感亲切。译作(2)在韵律方面就显得缺乏，偶尔的韵脚（尾韵），如 “mothers hand 和roam the land”, 没有体现出原诗韵味和感情。译文（3）的韵律为ababab，符合英语诗歌格 律习惯。读译文(4)原文时, 那饱含深情的母对子、子对母的爱, 字里行间无不透露得淋漓尽致。 无论是韵脚, 还是音节量都得优异于前者译文（3）。译文（6）将原诗的每句五言，也译成 每行抑扬格四音部。原诗第二、四、六行押韵, 译诗也同样。另外译文（3）和译文（6）样，对 “sews and sews” 的翻译得巧妙，叠词呈现的韵律效果在诗中表达得非常到位。一幅 母亲心急、手快、密密地一针一线地缝衣服的画面呈现在读者面前。让人产生想象的空间进 一步放大。译文（6）还运用了 “stray and stray” 对应 “迟迟归”，再现原诗的叠词和对兴的 修辞风貌, 可谓妙笔传神, 细致入微, 恰到好处。译文（7）中“密密缝：Closer and closer” 和 “迟迟归--delayed and delayed” 叠词翻译, 以及 “cotton coat” 头韵词的运用已现出译者的功 力和对原原文深刻的理解。也体现了是整体的美感。不仅可以使译文和原文更加贴切, 而且 可以准确的传达出原诗中的诗人所表达的心境, 同时也可以增强译文回旋的音乐性和悠长的 节奏感。加强抒情的感染, 激发欣赏者的审美的情趣。

\section{6. “词美” 对比}

\section{1 “游子吟”}

原诗题目为 “游子吟”，很显然是离家的子女写给母亲的诗歌。“吟” 是古典诗词的一 种名称, 英译为 (song or as a type of classical poetry)。如:吟卷(诗册; 诗稿); 吟草(诗稿); 吟轴(诗 卷; 诗册); 《秦中吟》等等。此处当然还有歌颂的深层含义, 歌颂母爱的伟大难以回报。而译 文 (3)、（4）将 “游子吟” 译成 “Song of the Parting Son” 从翻译的有效字数上看，“Song $\rightarrow$ 吟”, “Parting Son $\rightarrow$ 游子”, 体现出原诗歌所传递的简洁和深意。而且准确、明晰, 既 明确诗的体例, 也明确了作者的身份--儿子, 更是一位正要离开母亲的儿子。“吟” 还有 “低 吟，心里在述说” 的意思。这里也是儿子在默默述说对母亲的爱; （2）“For Her Son Who” 11 Be Away For A While” , 从题目上看不出作者是谁。好像母亲写给儿子的诗, 更像一篇现 代散文的题目, 所以看不出古诗的体例, 显然译者对古代诗体没有经过深入探究。从字数上 看, 此译文题目翻译的字数过多。“吟” 在此译文题目中没有翻译出 “吟诵” 的意义。“游 子”一词, 古时候指:出门在外或者是离开家乡在他乡生活的人或者离家远游的人。出处:

《汉书.高帝记下》: “游子悲 故乡。” 杜甫《梦李白》诗之二: “浮云终日行, 游子久不 至。”也作 “游子”。译文 (1) 中译为A Roamers Song, 是 “游荡者的歌” ，因为 “Roam ” 是 “to travel or walk about with no fixed purpose or direction; wander” 漫无目的的四处游走。 显然此情此景不合适。看不出母与子的关系，也看不出是写给母亲的诗。而译文（6）中 “游 子” 被译成 “Absent Son”。翻译不贴切，“absent” 有 “缺席的” 意思。译文（3）和（7） Parting 表示 “儿子正要离开母亲”。

\section{2 “慈母”}

译文（1）运用了“My Benevolent Mother”，其他翻译版本就是mother而已。此处较为 贴切, 充满热爱之情。译文 (2) 中doting可谓译作中的上乘之作。Doting 此处既可解释为: “excessively fond: doting parents” 即 “.溺爱的; 偏爱的意思”。一位溺爱孩子的母亲。“儿 行千里母担忧”，孩子无论多大只要在母亲面前永远都是孩子，也会永远受到母亲的溺爱; 另外doting这个词包含有: “ showing a decline of mental faculties, especially associated with old 
age; weak-minded” , 即 “;身体机能的退化老化; 思维糊涂的意思”。此处在读者眼前会呈现 出一幅画面: “年迈的母亲, 满头白发, 甚至有点糊涂, 而且手也不如年轻的时候那样灵活, 但是还是忙着给儿子做衣裳的情景”, 感人至深, 逼真形象, doting一语双关, 意义深遂, 令人深思。

\section{3 “线”}

译作(2)中译者将原诗中的 “线”，译出 “Needle and thread” 即 “一针一线”，显然是 增译的手法, 其实有显多余之嫌, 因为不出现 “needle（针）”, 人们也会联想到母亲是拿针 线在忙碌的情景。

\section{4 “密密缝”}

译文（1）中使用了mends, “修理, 修补” 的意思, “缝补旧衣服给儿子”。译文（3）处 理得可谓精妙: 其隐性逻辑关系显性化。“慈母手中线” 依据作者为 “From the threads a mothers hand weaves.” 原句全诗由代词和名词构成, 并不见动词的身影。但是在译文中译者增添了 weaves这一动词, 就把母亲穿针引线的动作清晰地刻画出来。这样读者就极容易联想到油灯 下, 头发花白的母亲在为儿子做衣裳的情景, 也更容易体会到母亲对儿子的爱以及诗人对母 亲的感恩和内疚的心情, 达到与诗人共鸣。其实weaves一词还有摇摇晃晃的走动, 译者联想 到了母亲年迈走路颠颠䈐簸的样子，反祄出母亲的伟大。叠词翻译（3）stitch by stitch和（4） sews and sews翻译的到位准确, 体现出原诗的韵味和风格。叠词显示人物的动态和心理、烘 托环境和氛围。译文 (7) 进行时态的运用增添了画面的动态感和鲜活感, flying, parting 和 fearing分别表示: 针线在衣上速度飞快地缝着, 表现出母亲着急的心情。生动形象, 画面感 强。

\section{7. 结束语}

译诗只是一种类似与原诗的形式, 是一件跟原诗的艺术效果相近的艺术品。不但可以比较 不同译者在还原原作信息、译作语言风格等方面的差异和特色之外, 也可以研究其翻译观。这 样不仅能够加深对原诗作者写作观和译者翻译观的了解, 而且对探讨以译者风格各异的成因 理论问题进行研究。诗歌翻译是一门艺术, 是一种再创作。本文仅对唐诗《游子吟》的几个译 作进行比较, 探讨旅游文化的汉译英策略, 试图解决旅游文化汉译英中出现的问题, 以便更好 地传播中国文化, 促进旅游国际化发展。

\section{致谢}

本文为2017年度沈阳市社会科学立项课题《国际化营商环境下沈阳旅游公示语规范性研 究》（编号:SYSK2017-23-18）研究成果, 负责人:赵凛 ; 本文为辽宁经济职业技术学院科 研一般项目《国际标准化环境下旅游景点公示语研究》 (Ljgykt-yb1703) 的成果, 负责人: 赵 凛。

\section{References}

[1] Gu zhengyang,Probing into English Translation of Chinese Ancient Poetry,National Defense Industry Press,pp.179-181,2012.

[2] Xu zhongjie, 200 Tang Poetry A Translation,Beijing Language and Culture University Press,pp207-208,1990.

[3] Gong jinghao,Selected English Translations of Tang Poetry,The Commercial Press,pp4-5,2006. 
[4] Cao shunfa,Approaching Beauty of form:Translation of Chinese Ancient Poetry,National Defense Industry Press,pp196-197,2007.

[5] Yangxiaorong, Translation Criticism Introduction, China Translation \& Publishing Corporation,p64-65,2005.

[6] Shiying zhou ,Selected Translation of Chinese Classical Poetry, Crown Publishing House.1987.

[7] Lvshuxiang,Comparative Study on English Translation,Zhonghua Book Company,2002.

[8] Lvshuxiang,One Hundred Quatrains by the Tang Poets English Translations of Old Gems,Hunan People's Publishing House, 1980.

[9] Xu Yuanchong,300Tang Poetry A New Translation,pp80,1988. 